\title{
Evaluation of Different Solid Media for Mass Production of Native Entomopathogenic Nematodes Heterorhabditis bacteriophora and Steinernema carpocapsae Isolated from Cotton Fields
}

\author{
N. Seenivasan \\ Department of Nematology, Tamil Nadu Agricultural University, \\ Coimbatore, Tamil Nadu, India
}

\begin{abstract}
Thirteen different plant and animal protein media such as nutrient agar medium-I, nutrient agar medium-II, Wouts medium, modified Wouts medium, wheat flour medium, modified wheat flour medium, egg yolk medium-I, egg yolk medium-II, modified egg yolk medium, dog biscuit medium, modified dog biscuit medium, bengal gram medium-I and bengal gram medium-II were tested for mass multiplication of entomopathogenic nematodes such as Heterorhabditis bacteriophora strain KKMH1 and Steinernema carpocapsae strain APKS2 by in vitro solid culture technique. Results showed that modified Wouts medium and nutrient agar medium-I multiplied significantly higher numbers of $39.02-39.14$ lakh IJs of $H$.. bacteriophora strain KKMH1 per $250 \mathrm{ml}$ flask. The IJs produced from these media were more virulent to cotton pest such as Helicoverpa armigera, Earias vitella and Spodoptera litura. For multiplication of Steinernema carpocapsae strain APKS2, modified dog biscuit medium and nutrient agar medium-I got significantly higher IJ populations of 49.69 - 52.31 lakh $/ 250 \mathrm{ml}$ flask. The IJs multiplied on these media caused $100 \%$ mortality of $H$. armigera, E. vitella and $S$. litura. The results of this study suggest that mass production of the $H$. bacteriophora strains KKMH1 on modified wouts medium or nutrient agar medium-I and S. carpocapsae strain APKS2 on modified dog biscuit medium or nutrient agar medium-I are promising option while promotion of these strains as potential bio-pesticide against cotton insect pests $H$. armigera, E. vitella and S. litura.
\end{abstract}

Keywords: Entomopathogenic nematodes, mass multiplication, different media composition, Virulence, Helicoverpa armigera, Earias vitella and Spodoptera litura, cotton.

Cotton (Gossypium spp.), popularly known as 'white gold', is an important cash crop of India. One of the prime challenges to attain high cotton production is damage caused by insect pests. Among insect pests of cotton, bollworm complex consisting of American bollworm Helicoverpa armigera Hub. (Lepidoptera: Noctuidae), spotted bollworm Earias vitella Fab. (Lepidopter: Noctuidae) and cotton leafworm Spodoptera litura (Fabricius) are most important pests affecting the cotton plants and they can cause yield loss of $20-80 \%$ [1,2]. The habit of developing resistance to many insecticides including Bt transgenic cotton necessitate to find out an alternate strategy to manage bollworms. In this situation, exploitation of naturally occurring entomopathogenic nematodes (EPN) from two families viz, Heterorhabditidae and Steinernematidae to develop biopesticide for the control of cotton bollworms is an ecologically sound novel approach. These nematodes are characterized by their ability to carry specific pathogenic bacteria, Photorhabdus with Heterorhabditidae and Xenorhabdus with Steinernematidae, which are released into the insect haemocoel after penetration of the insect hosts by the infective stage of the nematodes. Most biocontrol agents require days or weeks to kill the pest, but entomopathogenic nematodes with their symbiotic bacteria kill insects in 24-48 hr. Many cotton pests like bollworm Helicoverpa zea, fall armyworm Spodoptera frugiperda, beet armyworm Spodoptera exigua, cabbage looper Trichoplusia ni, tobacco budworm Heliothis virescens and the pink bollworm Pectinophora gossypiella are susceptible to entomopathogenic nematodes [3, 4]. The infectivity of EPN species Steinernema carpocapsae, S. riobravus and S. feltiae on H. arimigera and E. insulana was established earlier [5, 6]. Gassmann et al., [7] demonstrated the successful field control of pink bollworm, $P$. gossypiella using an EPN species Steinernema riobrave on cotton. 


\section{N. Seenivasan}

Exploring indigenous EPN in cotton fields of Tamil Nadu state in India, Seenivasan et al., [8] recovered 27 strains belonging to 16 Steinernema carpocapsae, 3 Steinernema siamkayai, 1 Steinernema monticolum and 7 Heterorhabditis bacteriophora from cotton ecosystem. Later, Seenivasan and Sivakumar [9] established that all the 27 EPN strains were suitable host for cotton bollworms $H$. armigera, E. vitella and $S$. litura. Among them, the strains of KKMH1 $(H$. bacteriophora) and APKS2 (S. carpocapsae) showed the advantages such as more virulence against $H$. armigera, E. vitelli and S. litura; high reproduction potential; tolerant to heat and desiccation [9]. The successful implementation of these EPN strains as potential bio-pesticide against cotton bollworms is possible only after standardization of suitable mass production technique. EPN can be multiplied by either in vivo or in vitro culture techniques. The in vivo production is very simple, but this method is labour intensive and mainly used to maintain EPN culture. The in vitro culture technique has more potential to mass produce EPN as it yield very high EPN with reduced cost, labour and equipment when compared to the in vivo production methods. Earlier EPN were grown on in vitro solid medium axenically, but later it was understood that presence of symbiotic bacterium is essential for multiplication of EPN. Nowadays in vitro culturing of EPN involves introduction of infective juveniles (IJs) to a monoculture of their symbiont either Photorhabdus or Xenorhabdus in the nutrient medium. The solid culture technology using ployether-polyurethane sponge has been proved the most successful method and is now exploited for mass production of Steinernema and Heterorhabditis species [10]. The nutritional composition of the culture medium is an important factor to determine the yield potential of particular EPN strain [11]. The inappropriate media composition apparently produces less virulent symbiotic bacteria which in turn may result in less pathogenic EPN with reduced storage stability. Hence, the present work was attempted to standardize suitable plant or animal based media to mass produce virulent $H$. bacteriophora (KKMH1) and $S$. carpocapsae (APKS2).

\section{Materials AND Methods}

\section{EPN culture}

Two EPN strains namely KKMH1 (H. bacteriophora) and APKS2 (S. carpocapsae), earlier isolated by baiting of soil samples from different cotton fields of Tamil Nadu, India were taken from the Department of Nematology, TNAU, Coimbatore, India. They were cultured in the laboratory at room temperature using last instar larvae of the rice grain moth, Carcyra cephalonica (Lepidoptera: Pyralidae) as described by Kaya and Stock [12]. The infective juveniles (IJs) releasing from $C$. cephalonica larval cadavers were collected in sterile distilled water using a modified White's trap [12], sterilized in formalin $(0.05 \%)$ solution and maintained on aerated sterile water in plastic tissueculture flasks at $15^{\circ} \mathrm{C}$. Before inoculation, IJs were surface sterilized by suspending in $0.1 \% \mathrm{HgCl}_{2}$ for 10 min followed by 3-4 time washing with distilled water by the method of centrifugation at $5000 \mathrm{rpm}$ for $5 \mathrm{~min}$.

\section{Symbiotic bacteria culture}

The EPN strains KKMH1 (H. bacteriophora) and APKS2 (S. carpocapsae) were made to infect $4^{\text {th }}$ instar larvae of $C$. cephalonica. Then $24 \mathrm{~h}$ later, the infected $C$. cephalonica were first surface sterilized with $70 \%$ ethanol, dissected aseptically and the infected hemolymph was streaked on plates containing NBTA medium (2.3 g nutrient agar, $0.025 \mathrm{~g}$ bromothymol blue and $0.004 \mathrm{~g}$ triphenyltetrazolium chloride in $100 \mathrm{ml}$ distilled water). The plates were incubated $25^{\circ} \mathrm{C}$ for $48 \mathrm{~h}$ and then Xenorhabdus spp. (bacterial colonies showing dark blue) from APKS2 and Photorhabdus spp. (bacterial colonies showing green) from KKMH1 were isolated and grown in nutrient broth. Xenorhabdus spp. and Photorhabdus spp. grown in nutrient broth $(3 \mathrm{~g}$ beef extract, $5 \mathrm{~g}$ peptone and 8 $\mathrm{g} \mathrm{NaCl}$ in $1 \mathrm{~L}$ of distilled water) was used as inoculum for solid in vitro culture. Bacteria containing $1 \times 10^{5} \mathrm{cfu} / \mathrm{ml}$ were used as inoculum.

\section{Evaluation of different media}

In vitro multiplication of $H$. bacteriophora KKMH1 and $S$. carpocapsae APKS2 were tried in 13 different plant and animal protein media viz., nutrient agar medium-I, nutrient agar mediumII, Wouts medium, modified Wouts medium, wheat flour medium, modified wheat flour medium, egg yolk medium-I, egg yolk medium-II, modified egg yolk medium, dog biscuit medium, modified dog biscuit medium, bengal gram medium-I and bengal gram medium-II. The composition of the medium per $100 \mathrm{ml}$ distilled water was detailed here; Nutrient agar medium I - beef extract $0.3 \mathrm{~g}$, peptone 0.5 
$\mathrm{g}$, agar $0.2 \mathrm{~g}, \mathrm{NaCl} 0.8 \mathrm{~g}$ and chicken fat $10 \mathrm{~g}$; Nutrient agar medium II - beef extract $0.3 \mathrm{~g}$, peptone $0.5 \mathrm{~g}$, agar $0.2 \mathrm{~g}, \mathrm{NaCl} 0.8 \mathrm{~g}$ and soybean oil $5 \mathrm{~g}$; Wout's medium - nutrient broth $0.88 \mathrm{~g}$, yeast extract $0.32 \mathrm{~g}$, soyflour $14.40 \mathrm{~g}$ and groundnut oil $10.40 \mathrm{~g}$; Modified Wout's medium - nutrient broth $0.88 \mathrm{~g}$, yeast extract $0.32 \mathrm{~g}$; soyflour $14.40 \mathrm{~g}$, groundnut oil $10.40 \mathrm{~g}$ and beef extract $5 \mathrm{~g}$; Wheat flour medium - wheat flour $15.0 \mathrm{~g}$, kabuligram flour $5 \mathrm{~g}$, beef extract $5 \mathrm{~g}$, yeast extract $6 \mathrm{~g}$, agar $1 \mathrm{~g}$ and coconut oil $6.0 \mathrm{~g}$; Modified wheat flour medium - wheat flour $15.0 \mathrm{~g}$, soyflour $5.0 \mathrm{~g}$, beef extract $5.0 \mathrm{~g}$, yeast extract $1 \mathrm{~g}$, and groundnut oil $10.0 \mathrm{~g}$; Egg yolk medium I - spray dried egg yolk powder (SDEY) 7.0 $\mathrm{g}$, yeast extract $2.0 \mathrm{~g}, \mathrm{NaCl} 0.80 \mathrm{~g}$ and oil $15.0 \mathrm{~g}$; Egg yolk medium II - SDEY $10.0 \mathrm{~g}$, yeast extract $5.0 \mathrm{~g}, \mathrm{NaCl} 0.80 \mathrm{~g}$ and oil $12.0 \mathrm{~g}$; Modified egg yolk medium - egg yolk $7.0 \mathrm{~g}$,soyflour $20 \mathrm{~g}$, yeast extract $2.0 \mathrm{~g}, \mathrm{NaCl} 0.80 \mathrm{~g}$ and oil $15 \mathrm{~g}$ : Dog biscuit medium - dog biscuit $15.0 \mathrm{~g}$, yeast extract $1.0 \mathrm{~g}$, peptone $3.0 \mathrm{~g}$, agar $2.0 \mathrm{~g}$ and oil $10.0 \mathrm{~g}$; Modified Dog biscuit medium - dog biscuit 20.0 $\mathrm{g}$, pepton $0.5 \mathrm{~g}$, yeast extract $1.0 \mathrm{~g}$, beef extract $5 \mathrm{~g}$ and oil $7.0 \mathrm{~g}$; Bengal gram medium I nutrient broth $1.5 \mathrm{~g}$; yeast extract $0.7 \mathrm{~g}$, bengal gram flour $20 \mathrm{~g}$ and ground nut oil $20 \mathrm{~g}$; and Bengal gram medium II - nutrient broth $1.75 \mathrm{~g}$, yeast extract $0.5 \mathrm{~g}$, bengal gram flour $20 \mathrm{~g}$ and gingelly oil $32.5 \mathrm{~g}$. Each media were poured into $250 \mathrm{ml}$ volumetric flasks containing sterile 6 pieces of $1.5 \mathrm{~cm}^{3}$ polyurethane sponge. Each media were replicated 5 times (one flask $=$ one replicate). Then the flasks were sterilized at $10 \mathrm{psi}$ for $10 \mathrm{~min}$ in autoclave. Concerned symbiont bacterial culture were inoculated in each flask, shacked well and incubated $25^{\circ} \mathrm{C}$ for $48 \mathrm{~h}$ to assure bacterial growth. Then concerned EPN strain IJs were inoculated at 5000 per flasks and incubated for 20 days at $25^{\circ} \mathrm{C}$. Then IJs produced from different media were washed several times with distilled water and harvested using 625 mesh $(20 \mu \mathrm{m})$ sieve. The number of IJs were counted under steriozoom microscope after appropriate dilutions. Then IJs were store in $0.05 \%$ formalin suspension at refrigerator and aerated once in two days.

\section{Virulence test}

The IJs of $H$. bacteriophora KKMH1 and $S$. carpocapsae APKS2 multiplied form different media were then tested for their virulence against cotton bollworms $H$. armigera, E. vitella and $S$. litura. The test insect larvae $(H$. armigera, $E$. vittella and $S$. litura) were collected from a standing cotton crop on TNAU farm and from the farmer's fields at Thondamuthur village in Coimbatore district of Tamil Nadu. They were sorted out and the fourth instar larvae of uniform size were used in the experiments. The test were conducted in 6-cm-diam petri dishes lined with moist filter paper disc. Five forth instar larvae of $H$. armigera, E. vittella and $S$. litura were put in petri dishes lined with filter paper. Then $1 \mathrm{ml}$ of appropriate EPN strain multiplied in different media containing 1000 IJs were applied to the petri dishes. Control plates received only $1 \mathrm{ml}$ distilled water. The dishes were sealed with parafilm, arranged in a completely randomized design (CRD) and incubated at room temperature. Each treatment consisted of five replicates (One Petri dish $=$ one replicate). After 4 days, larval mortality was recorded. The dead insects were dissected in Ringers solution to confirm the death by EPN. The experiments were repeated once.

\section{RESUlTS AND DISCUSSION}

The number of IJs of $H$. bacteriophora strain KKMH1 harvested from different test media and their virulence on $H$ armigera, E vitella and $S$. litura are presented in table 1 . The multiplication of $H$. bacteriophora strain KKMH1 on different media ranged from $6.32-39.17$ lakh IJs/250 ml flasks. The Modified wout's medium and Nutrient agar medium-I were recorded significantly higher multiplication of 39.02 - 39.14 lakh IJs/250 ml flask which were statistically on par. The moderate multiplication of 25.67 - 26.73 lakh IJs/250 ml flask was observed in Nutrient agar medium-II and Wout's Medium. The multiplication was significantly least in Bengal gram medium-I and Bengal gram medium-II. The wheat flour medium, modified wheat flour medium, egg yolk I, egg yolk II, modified egg yolk medium, dog biscuit medium did not produce any $H$. bacteriophora IJs and hence these media were considered not suitable for mass production of H. bacteriophora strain KKMH1. Hatab and Gaugler [11] reported that the composition of in vitro solid culture media have the great influence on multiplication of $H$. bacteriophora and increasing the lipid quantity and quality of media lead to tremendous increase in IJs yield. Similarly, in this study the Modified wout's medium containing beef extract and Nutrient agar medium-II having chicken fat were yielded more IJs of $H$. bacteriophora strain KKMH1. Earlier Hussaini et al., [13] observed the highest multiplication of Heterorhabditis indica on Wout's medium. In this 


\section{N. Seenivasan}

study the Wout's medium yielded relatively less IJs of $H$. bacteriophora, but addition of beef extract improved the IJs yield. Many studies proved the importance of media composition, which should satisfy growth conditions of both nematode and its symbiont [14]. This study indicate that media composition of wheat flour medium, modified wheat flour medium, egg yolk I, egg yolk II, modified egg yolk medium, dog biscuit medium are not suitable for growth of Photorhabdus spp associated with H. bacteriophora strain KKMH1.

Table1. Multiplication of Heterorhabditis bacteriophora strain KKMH1 by in vitro solid culture on different artificial media and the virulence of IJs harvested from different media on $4^{\text {th }}$ instar larvae of Helicoverpa armigera, Earias vitella and Spodoptera litura.

\begin{tabular}{|c|c|c|c|c|}
\hline \multirow[t]{2}{*}{ Test media } & \multirow{2}{*}{$\begin{array}{l}\text { Number of IJs } \\
\text { harvested per } \\
250 \mathrm{ml} / \mathrm{flask} \\
\text { (in lakhs) }\end{array}$} & \multicolumn{3}{|c|}{ Larval mortality (\%) } \\
\hline & & $\begin{array}{c}\text { Helicoverpa } \\
\text { armigera }\end{array}$ & Earias vitella & $\begin{array}{l}\text { Spodoptera } \\
\text { litura }\end{array}$ \\
\hline Nutrient agar medium I & $39.02 \mathrm{a}$ & $100.0 \mathrm{a}$ & $100.0 \mathrm{a}$ & $100.0 \mathrm{a}$ \\
\hline Nutrient agar medium II & $25.67 \mathrm{~b}$ & $94.3 \mathrm{a}$ & $92.5 \mathrm{~b}$ & $94.0 \mathrm{a}$ \\
\hline Wout's Medium & $26.73 \mathrm{~b}$ & $95.4 \mathrm{a}$ & $94.6 \mathrm{a}$ & $96.3 \mathrm{a}$ \\
\hline Modified wout's medium & $39.14 \mathrm{a}$ & $100.0 \mathrm{a}$ & $100.0 \mathrm{a}$ & $100.0 \mathrm{a}$ \\
\hline Wheat flour medium & $\mathrm{X}$ & - & - & - \\
\hline Modified Wheat flour medium & $X$ & - & - & - \\
\hline Egg yolk I & $\mathrm{X}$ & - & - & - \\
\hline Egg yolk II & $\mathrm{X}$ & - & - & - \\
\hline Modified egg yolk medium & $\mathrm{X}$ & - & - & - \\
\hline Dog biscuit medium & $X$ & - & - & - \\
\hline Modified Dog biscuit medium & $\mathrm{X}$ & - & - & - \\
\hline Bengal gram medium I & $6.32 \mathrm{c}$ & $72.6 \mathrm{~b}$ & $64.5 \mathrm{c}$ & $78.4 \mathrm{~b}$ \\
\hline Bengal gram medium II & $9.41 \mathrm{c}$ & $78.6 \mathrm{~b}$ & $70.2 \mathrm{c}$ & $84.6 \mathrm{~b}$ \\
\hline CD at 5\% & 5.82 & $7.32 \mathrm{~b}$ & 6.95 & 8.42 \\
\hline SED & 2.61 & 3.28 & 3.16 & 3.86 \\
\hline
\end{tabular}

$\mathrm{X}$ - No multiplication; Means followed by the same letter in columns are not significantly different at $\mathrm{P}<0.05$ according to Duncan's multiple rang test.

The significant variation in the virulence of $H$. bacteriophora IJs produced from different media was observed (Table 1). The IJs produced from Modified wout's medium and Nutrient agar medium-I caused $100 \%$ mortality of $H$. armigera, E. vitella and S. litura where as IJs multiplied on Bengal gram medium-I and Bengal gram medium-II caused significantly lease mortality of $H$. armigera $(72.6-78.6 \%)$, E. vitella $(64.5-70.2 \%)$ and S. litura $(78.4-84.6 \%)$. The IJs produced from Nutrient agar medium-II and Wout's Medium caused $94.3-95.4 \%$ mortality of $H$. armigera, $92.5-94.6 \%$ mortality of E. vitella and $94.0-96.3 \%$ mortality of S. litura. The pathogenicity of EPN species $H$. bacteriophora against $H$. armigera, E. vitella and S. litura was reported earlier [9]. This study confirmed the earlier findings and established the lethal effect of IJs multiplied on different media. In addition, this study showed that the virulence of $H$. bacteriophora IJs varied when multiplied on different media. Similar results of the differences in the quality of $H$. bacteriophora IJs produced from different culture media was reported by Hatab and Gaugler [11]. They observed that the sterol and oleic acid contents of IJs is highly variable when they multiplied on different media and virulent populations are rich in sterol and oleic acid contents. Susurluk et al., [15] also observed $76-100 \%$ mortality of Galleria mellonella larvae due to different batches of $H$. bacteriophora IJs multiplied on different media which is in line with our results.

The $S$. carpocapsae APKS2 was multiplied on 11 media out of 13 tried (Table 2). The Wheat flour medium and Dog biscuit medium did not multiply $S$. carpocapsae. There was significant variation exist among 11 media to produce $S$. carpocapsae IJs. The Modified Dog biscuit medium and Nutrient agar medium-I got significantly higher number of IJs than other test media. The multiplication in these media was 49.69 - 52.31 lakh IJs/flask. The Modified Wheat flour medium, Bengal gram medium-I and Bengal gram medium-II recorded the significantly least production of 9.62 - 13.26 lakh IJs/flask. The results are in accordance with Hussaini et al., [13] who observed that Wout's medium, modified egg yolk, soyflour cholesterol media and modified dog biscuit yielded highest number of $S$. carpocapsae IJs. The potential of Nutrient agar medium-I to 
Evaluation of Different Solid Media for Mass Production of Native Entomopathogenic Nematodes Heterorhabditis bacteriophora and Steinernema carpocapsae Isolated from Cotton Fields

get highest number of EPN IJs also demonstrated by Rabhaji [16]. Somwong and Petcharat [17] tried different media composition and produced 2.44 - 5.54 lakh IJs $S$. carpocapsae. This result is similar to that of present study.

Table 2. Multiplication of S. carpocapsae APKS2 by in vitro solid culture on different artificial media and the virulence of IJs harvested from different media on $4^{\text {th }}$ instar larvae of Helicoverpa armigera, Earias vitella and Spodoptera litura.

\begin{tabular}{|c|c|c|c|c|}
\hline \multirow[t]{2}{*}{ Test media } & \multirow{2}{*}{$\begin{array}{r}\text { Number of IJs } \\
\text { harvested per } \\
250 \mathrm{ml} / \text { flask } \\
\text { (in lakhs) }\end{array}$} & \multicolumn{3}{|c|}{ Larval mortality (\%) } \\
\hline & & $\begin{array}{c}\text { Helicoverpa } \\
\text { armigera }\end{array}$ & Earias vitella & $\begin{array}{l}\text { Spodoptera } \\
\text { litura }\end{array}$ \\
\hline Nutrient agar medium I & $49.69 \mathrm{a}$ & $100.0 \mathrm{a}$ & $100.0 \mathrm{a}$ & $100.0 \mathrm{a}$ \\
\hline Nutrient agar medium II & $38.72 \mathrm{~b}$ & $96.2 \mathrm{a}$ & $94.3 \mathrm{a}$ & $97.6 \mathrm{a}$ \\
\hline Wout's Medium & $23.61 \mathrm{c}$ & $94.5 \mathrm{a}$ & $92.8 \mathrm{a}$ & $96.3 \mathrm{a}$ \\
\hline Modified wout's medium & $18.52 \mathrm{c}$ & $84.3 \mathrm{~b}$ & $82.6 \mathrm{~b}$ & $83.6 \mathrm{~b}$ \\
\hline Wheat flour medium & $\mathrm{X}$ & - & - & - \\
\hline Modified Wheat flour medium & $9.62 \mathrm{~d}$ & $80.7 \mathrm{~b}$ & $79.2 \mathrm{~b}$ & $80.3 \mathrm{~b}$ \\
\hline Egg yolk I & $34.36 \mathrm{~b}$ & $100.0 \mathrm{a}$ & $100.0 \mathrm{a}$ & $100.0 \mathrm{a}$ \\
\hline Egg yolk II & $19.64 \mathrm{c}$ & $78.5 \mathrm{~b}$ & $76.4 \mathrm{~b}$ & $77.4 \mathrm{~b}$ \\
\hline Modified egg yolk medium & $43.13 \mathrm{~b}$ & $100.0 \mathrm{a}$ & $100.0 \mathrm{a}$ & $100.0 \mathrm{a}$ \\
\hline Dog biscuit medium & $\mathrm{X}$ & - & - & - \\
\hline Modified Dog biscuit medium & $52.31 \mathrm{a}$ & $100.0 \mathrm{a}$ & $100.0 \mathrm{a}$ & $100.0 \mathrm{a}$ \\
\hline Bengal gram medium I & $11.64 \mathrm{~d}$ & $84.2 \mathrm{~b}$ & $81.3 \mathrm{~b}$ & $82.4 \mathrm{~b}$ \\
\hline Bengal gram medium II & $13.26 \mathrm{dc}$ & $79.5 \mathrm{~b}$ & $78.2 \mathrm{~b}$ & $80.5 \mathrm{~b}$ \\
\hline $\mathrm{CD}$ at 5\% & 6.84 & 8.63 & 8.73 & 8.82 \\
\hline SED & 3.38 & 4.12 & 3.95 & 4.26 \\
\hline
\end{tabular}

$\mathrm{X}-$ No multiplication; Means followed by the same letter in columns are not significantly different at $\mathrm{P}<0.05$ according to Duncan's multiple rang test.

The pathogenicity of EPN species $S$. carpocapsae against $H$. armigera, E. vitella and $S$. litura was established by Seenivasan and Sivakumar [18]. This study showed that the virulence of $S$. carpocapsae APKS2 varied significantly when multiplied on different media (Table 2). The IJs multiplied on Nutrient agar medium-I, Egg yolk-I, Modified egg yolk medium and Modified Dog biscuit medium were highly virulent to $H$. armigera, E. vitella and $S$. litura which caused $100 \%$ mortality. The IJs grown in other media caused $<100 \%$ mortality. The IJs developed on Modified wout's medium, Modified wheat flour medium, Egg yolk-II, Bengal gram medium-I and Bengal gram medium-II were significantly least virulent which caused $78.5-84.3 \%$ mortality of $H$. armigera, $76.4-82.6 \%$ mortality of $E$. vitella and $77.4-83.6 \%$ mortality of $S$. litura. Somwong and Petcharat [17] found that mortality of $S$. litura ranged from $40-100 \%$ due to IJs of $S$. carpocapsae depending on the media from which it was multiplied. This result is comparable to that of present study.

In conclusion, the mass multiplication of H. bacteriophora strain KKMH1in Modified wout's medium or Nutrient agar medium-I and S. carpocapsae strain APKS2 on Modified dog biscuit medium or Nutrient agar medium-I can be recommended for commercial exploitation as they generated more IJs with high virulence against cotton pests $H$. armigera, E. vitella and S. litura.

\section{ACKNOWLEDGEMENT}

The author is grateful to the Life Science Research Board, Defense Research and Development Organization, New Delhi, India for the financial support through a grant (No. DLS/81/48222/LSRB136/FSB/2007).

\section{REFERENCES}

[1] Dhaliwal G.S., Jindal V., Dhawan A.K., Insect pest problems and crop losses: changing trends, Indian J. Ecol. 37, 1-7 (2010)..

[2] Seenivasan N., Management of Root-knot nematode, Meloidogyne incognita with organic amendments in medicinal Coleus, Ann. Plant Prot. Sci. 18, 472-476 (2010). 
[3] Gaugler R., Entomopathogenic nematology, CABI Publishing, Wallingford, Oxon, UK. 388 (2001).

[4] Seenivasan N., Sundarababu R., Management of Rotylenchulus reniformis with bio-control agents in cotton, Ann. Plant Prot. Sci. 15, 454-457 (2007).

[5] Glazer I., Effects of infected insects on secondary invasion of steinernematid entomopathogenic nematodes, Parasitol. 114, 597-604 (1997).

[6] Seenivasan N., Murugan V.T., Optimization of delivery methods for Pseudomonas fluorescens in management of rice root nematode, Hirschmanniella gracilis. Ann. Plant Prot. Sci. 19, 188192 (2011).

[7] Gassmann A.J., Stock S P., Carriere Y., Tabashnik B.E., Effect of entomopathogenic nematodes on the fitness cost of resistance to Bt toxin Cry1 Ac in pink bollworm (Lepidoptera: Gelechiidae), J. Econ. Entomol. 99, 920-926 (2006).

[8] Seenivasan N., Prabhu S., Makesh S., Sivakumar M., Natural occurrence of entomopathogenic nematode species (Rhabditida: Steinernematidae and Heterorhabditidae) in cotton fields of Tamil Nadu, India. J. Nat. Hist. 46, 2829-2843 (2012).

[9] Seenivasan N., Sivakumar M., Bio-prospecting of naturally occurring entomopathogenic nematodes (Rhabditida: Steinernematidae and Heterorhabditidae) isolated from cotton fields at Tamil Nadu, India. Conference proceedings, 2nd International Symposium of Bio-Pesticides and Eco-toxicological Network, pp. 57, (2012).

[10] Tabassum K.A., Shahina F., In vitro mass rearing of different species of entomopathogenic nematodes in monoxenic solid culture, Pakistan J. Nematol. 22, 167 - 175 (2004).

[11] Hatab M.A., Gaugler R., Diet composition and lipids of in vitro-produced Heterorhabditis bacteriophora, Biolog. Control. 20, 1-7 (2001).

[12] Lacey L.A., Manual of techniques in insect pathology, Techniques in insect nematology, SanDiego, CA, USA.: Academic Press, 1997, ch 7, pp. 281-324.

[13] Hussaini S.S., Singh S.P., Parthasarathy R., Shakeela V., In vitro production of entomopathogenic nematodes in different artificial media, Indian J. Nematol. 32, 44-46 (2002).

[14] Seenivasan N., Sundarababu R., Devrajan K., Rajendran G., Influence of VAM fungi on cotton (Gossypium barbadense L.) infested with reniform nematode, Indian J. Nematol. 33, 52-55 (2003)..

[15] Susurluk I.A., Kongu Y., Ulu T.C., Quality control of in vitro produced Heterorhabditis bacteriophora (Rhabditida: Heterorhabditidae) strains isolated from Turkey, Turkish J. Entomol. 37, 283-291 (2013).

[16] Rabhaji P.P., Pathogenicity, mass production and efficacy of entomopathogenic nematode, Heterorhabditis indica. $\mathrm{PhD}$ thesis, University library, MPKV, India. pp. 214, (2013).

[17] Somwong P., Petcharat J., Culture of the entomopathogenic nematode Steinernema carpocapsae (Weiser) on artificial media, ARPN J. Agric. Biol. Sci. 7, 229-232 (2012).

[18] Seenivasan N., Sivakumar M.., Screening for environmental stress-tolerant entomopathogenic nematodes virulent against cotton bollworms, Phytoparasitica. 42, 165-177 (2014). 